\title{
The Usage of Crumb Rubber Filtration and UV Radiation for Ballast Water Treatment
}

\author{
Trika Pitana ${ }^{1}$, Maya Shovitri ${ }^{2}$, Haris Nur Fauzi ${ }^{3}$
}

\begin{abstract}
- this research is aimed to build ship's ballast water treatment prototipe that used to inactivate microbial water patogen in ballast water to produce unpolluted ballast water that can be standardised by IMO Ballast Water Management Convention. A simple concept that used in the development of this prototype is by draining ballast water with capacity at 5 Ipm, $10 \mathrm{lpm}$ and $20 \mathrm{lpm}$ into alternative filtration crumb rubber and UV reactor. In the filtration process using crumb rubber, ballast water will be filtered with the precision filtration up to 50 micron, while in the $\mathrm{UV}$ reactor ballast water will be illuminated by UV-C with maksimum dose $16,58 \mathrm{~mW} / \mathrm{cm} 2$. Finally, the study shows the performance of alternative filtration of crumb rubber and UV-C irradiation on microbial water phatogen, and at what UV-C dose ballast water treatment prototipe can inactivate microbial water phatogens, which are complying with IMO Ballast Water Management Convention ANNEX D.
\end{abstract}

Keywords - ballast water treatment, crumb rubber, UV-C, IMO Ballast Water Management Convention

\section{INTRODUCTION}

B allast water is very important to keep the savety operational of ship. Ballast water is used to control trim, draft, stability and tention on ships hull that caused by adverse ocean conditions or as a result of changes in cargo weight[1]. According to [2], besides giving positive impact for ship, ballast water can make major threats for environment, publict health and economy. This problem is due to the spread of Invasive Alien Species (IAS) or Harmful Aquatic Organism and Pathogens (HAOP) through ballast water medium. To solve the problem, in 2004 IMO issued Ballast Water Management Convention which required ships using ballast water treatment sys ${ }^{1}$ tem to allow only disposing of less than 10 living organisms of more than or equal to 50 micrometers per $1 \mathrm{~m} 3$. And for microorganisms that hold between 10 and 50 micrometers, only 10 microorganisms can be removed every 1 millimeter. As for the type of microbe, should not exceed the concentration that has been set. For vibrio cholerae less than $1 \mathrm{cfu}$ per $100 \mathrm{ml}$. For Escherichia coli less than 250 cfu per $100 \mathrm{ml}$. For intestinalentercocci less than 100 cfu.

To fulfill the requirements of IMO BWT Convension several ballast water treatment methods were developed on the ship, such as filtration and UV irradiation. To continue the developed research, in this research will be conducted study on design of ballast water treatment prototipe by using alternative filtration using crumb rubber and UV radiation rays to destroy microbial water pathogens. With this research will be known how the performance of crumb rubber when used as a water ballast filter and also known how UV reactor design that

Trika Pitana, Departement of Marine Engineering, InstitutTeknologiSepuluhNopember, Surabaya, 60111, Indonesia. Email : trika@its.ac.id

Maya ShovitriDepartement of Department of Biology, InstitutTeknologiSepuluhNopember, Surabaya, 60111, Indonesia. Email : mshovitri@gmail.com

HarisNurFauzi, Departement of Marine Engineering, InstitutTeknologiSepuluhNopember, Surabaya, 60111, Indonesia. Email : harisnf50@gmail.com can work effectively and efficiently and can produce ballast water that can be standardized by IMO Ballast Water Management.

Zhijian Tang, et al., (2008) has observed the effectiveness of filtration produced by sand, crumb rubber, and the combination betwen sand and crumb rubber. The effectiveness of this study is based on the water turbidity level, the number of pithoplangton and the amount of zooplangton.

Z. J. Ren, et al., (2016) has undertaken research to understand the potential technology of UV irradiation to kill microorganisms in ship's ballast water using static and dynamic experiments. Static experiments were used to determine the effect of UV doses on inactivation of microorganisms, whereas dynamic experiments were used to study the effects of water capacity on the inactivation of microorganisms.

From related work in previous research above, they have studied the performance of crumb rubber and uv filtration in ballast water treatment. Hence in this paper will be presented research on the performance of filtration of crumb rubber and UV irradiation which are installed together in a prototype of ballast water treatment in inactivating pathogenic water microorganisms.

\section{DEVELOPEMENT OF BALLAST WATER TREATMENT PROTOTIPE}

\subsection{UV-C Radiation}

UV-C is a type of ultraviolet light spectrum that can be absorbed by ribonucleic acid (RNA) protein and deoxyribonucleic acid (DNA). UV-C has a wavelength of $200 \mathrm{~nm}-300 \mathrm{~nm}$. At the wavelength owned by UV-C willmakes the bacteria die easily when exposed by those rays. Therefore, in the water treatment system, it can be used UV-C light to turn off the microbial water pathogens (Liu, 2005).

In this research, the typeof UV-C will be used. Those type has a power of 30 watts with a length around $57 \mathrm{~cm}$ and used two equipments. Both of these lamps will be mounted on a UV reactor that has a length of $53 \mathrm{~cm}$ and a diameter of $9,7 \mathrm{~cm}$. 


\subsection{Crumb Rubber Filtration}

Crumb rubber are chunks of rubber made from raw rubber that is pressed into sheets then cut into small pieces. In addition, crumb rubber can also be made from waste tires that are cut and milled to the desired size and then cleaned and removed any metal particles contained in it. In this research, crumb rubber filter is design with internal diameter of $6.5 \mathrm{~cm}$ and filter depth of $20 \mathrm{~cm}$. The crumb rubber media used in this study is made from rubber waste motorcycle tires are cut small on the size of $5 \mathrm{~mm}$. In this research is also used the use of carbon filters as filter media on the prototype to be a benchmark filtering performance performed by crumb rubber filters. The carbon filter used has a screening precision of 5 microns.

\subsection{Prototipe Working Scheme}

Ballast water treatment prototype in this study was built using the following working scheme

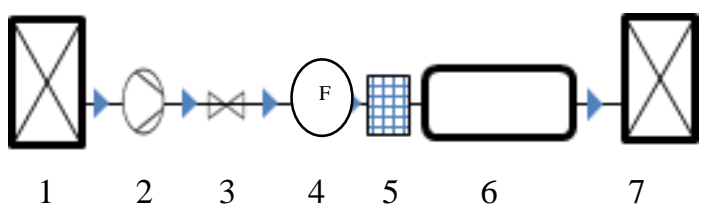

Fig.1 Ballast water treatment working scheme

\section{Where :}

$1=$ existing water tank

$2=$ water pump

$3=$ regulating valve

$4=$ flow meter

$5=$ filter

$6=\mathrm{UV}$ reactor

$7=$ processed water tanks
Based on the working diagram above, ballast water treatment prototipe consists of tank number one which serves as a reservoir of seawater in the existing condition. Water in tank number one will be pumped into the filter with a predetermined capacity. The Capacity of ballast water in the prototipe is regulated using a regulating valve located on the discharge side of the pump. When adjusting the ballast water capacityusing ball valve, it is also used the monitoring function on flow meter which is located between ball valve and flow meter. This monitoring is conducted to determine the amount of water capacity in the system and to ensure whether it has been in accordance with the variation of the predetermined capacity. After coming out of the flow meter, ballast water will flow into filter to undergo a process of sediment filtering and filters all of microbes that have size above 50 micron. After that, the water will flow into UV reactor to undergo microbial inactivation process. In UV reactor there are two 30 watt UV-C lamp. The dose of UV light irradiation on this reactor will be varied by regulating the voltage of UV lamp using an electrical regulator. Upon exiting the UV reactor, ballast water will be accommodated in the processed tank. From this tank will be taken water samples to analyze the amount of microbes contained in ballast water by using Total Plate Count (TPC) method.

\subsection{Prototipe Design Drawing}

Figure Bellow is the design drawing of ballast water treatment prototype using a combination of crumb rubber filtration and UV radiation.

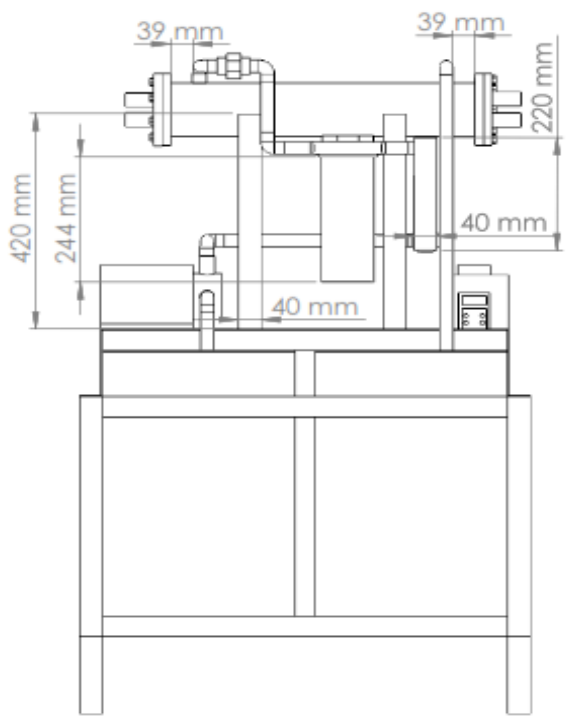

Fig.2 Ballast water treatment prototipe front view 


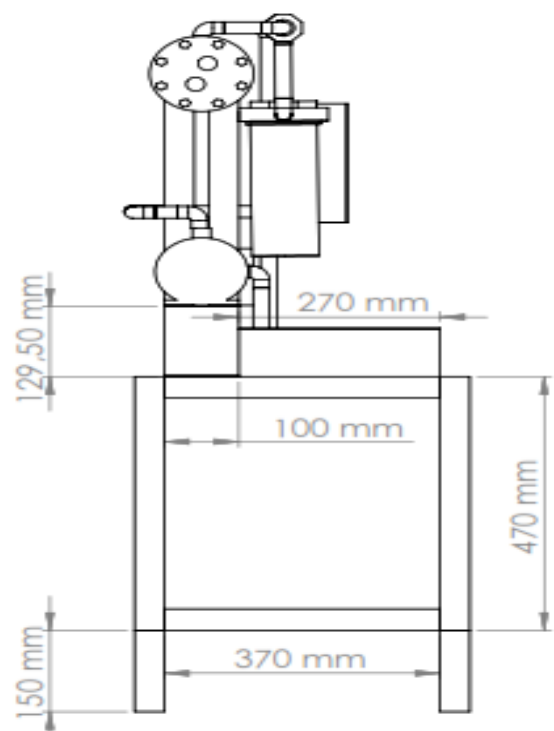

Fig.3 Ballast water treatment prototipe side view

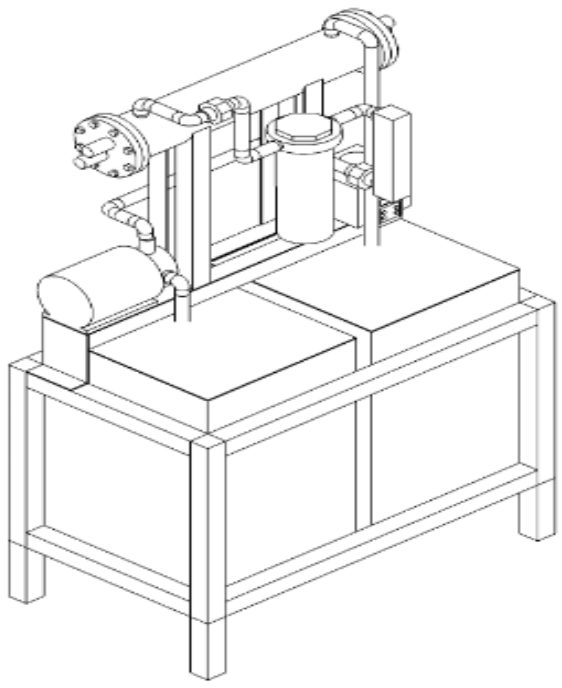

Fig.4 Ballast water treatment prototipe 3D view 


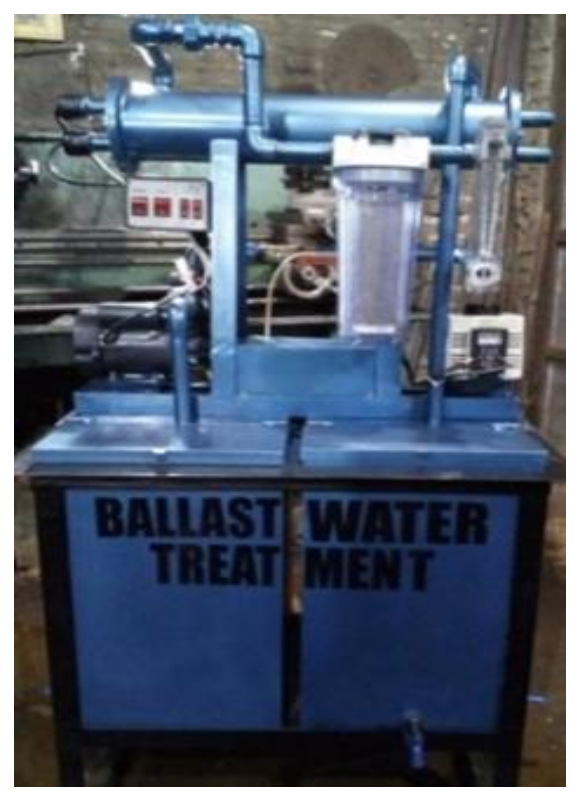

Fig.5 Ballast water treatment prototipe

\subsection{Experiment}

In the experiment, seawater will be pumped into ballast water prototype with a variablecapacitythat shown at Table 1. In addition, the uv dose was also varied to determine the relationship between the amount of ballast water capacity and UV doses that required for pathogenic microbial water inactivation in seawater (Table 1).After coming out of the prototype, processed water was tested on the amount of its microbial content using TPC method. TPC method is a method of microbial calculation using a medium of growth in the form of gel. The processed seawater obtained from the prototype will be diluted from $10^{-4}$ to $10^{-7}$ ( Figure 9), then each sample will be incubated for 24 hours into the medium in order for living microbes to grow. After 24 hours microbes will be observed then put into formula bacteria $/ \mathrm{ml}=$ number of colonies $\mathrm{x} 1 / \mathrm{fp}$ [3] to produce the amount of microbes that written with units of Colony.

TABLE 1.

TABLE OF SEAWATER TREATMENT EXPERIMENTS

\begin{tabular}{cccll}
\multicolumn{5}{c}{ TABLE OF SEAWATER TREATMENT EXPERIMENTS } \\
$\begin{array}{c}\text { Eksperiment } \\
\text { number }\end{array}$ & Debit $(\mathrm{lpm})$ & $\begin{array}{l}\text { Number of } \\
\text { UV dose } \\
(\mathrm{mW} / \mathrm{cm} 2)\end{array}$ & $\begin{array}{l}\text { Number of } \\
\text { microbes A } \\
\text { alive } \\
\text { microbes B } \\
(\mathrm{Cfu} / \mathrm{ml})\end{array}$ \\
\hline 1 & 5 & 7,10 & \\
\hline 2 & 10 & 7,10 & \\
\hline 3 & 20 & 7,10 & \\
\hline 4 & 5 & 14,20 & \\
\hline 5 & 10 & 14,20 & \\
\hline 6 & 20 & 14,20 & \\
\hline 7 & 5 & 16,58 & \\
\hline 8 & 10 & 16,58 & \\
\hline 9 & 20 & 16,58 & \\
\hline$*$ A : Carbon filtration & & \\
*B : Crumb rubber filtration & &
\end{tabular}




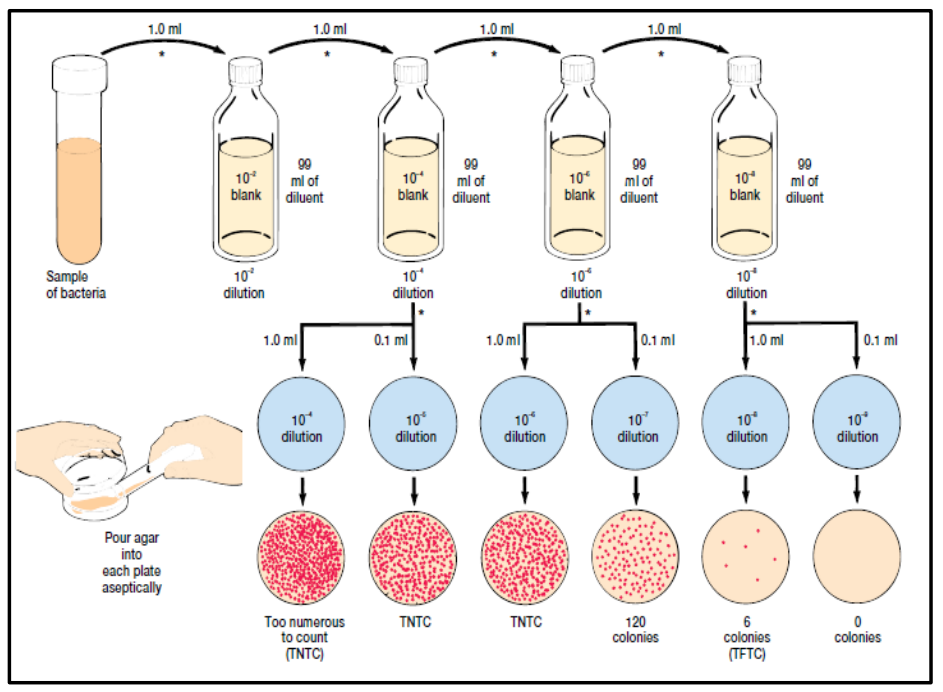

Fig.9 Procedure of quantification by Total Plate Countmethod

\section{Result And Discussion}

\subsection{Microbial Content In Sea Water Under}

ExistingConditions

Analysis of the amount of microbial content in seawater, basedon the existing condition was doneusing Total Plate Count(TPC) method. Those methodis analyzing the growth ofa bacteria grower in the form of $\mathrm{Na}$. In this analysis, water sample that used is water sample from Kenjeran. After being observed by TPC method, Kenjeran sea water sample contain $1.31 \mathrm{x}$ $10^{5} \mathrm{cfu}$.
3.2 Quantitative Analysis of Microbial Water Using TPC Method With Sterile Aquades Solvent

The analysis of microbial content on sea water is used aqueous solution as a $\mathrm{Na}$ solventmedium. A sterile aquades solution is used as a $\mathrm{Na}$ solvent to meet the protocol of making bacteria-growing medium on TPC method. From the observation the number of microbes that have been implemented using this method results as in Table 2.

TABLE 2.

TABLE OF MICROBIAL QUANTITATIVE ANALYSIS USINC TPC AND STERILE AQUADES SOLVENT

\begin{tabular}{ccccc}
\hline $\begin{array}{c}\text { Eksperiment } \\
\text { number }\end{array}$ & Debit (lpm) & $\begin{array}{c}\text { UV dose } \\
(\mathrm{mW} / \mathrm{cm} 2)\end{array}$ & $\begin{array}{c}\text { Number } \\
\text { of alive } \\
\text { microbes } \\
\mathrm{A}(\mathrm{Cfu} / \mathrm{ml})\end{array}$ & $\begin{array}{c}\text { Number } \\
\text { of alive } \\
\text { microbes } \\
\mathrm{B}(\mathrm{Cfu} / \mathrm{ml})\end{array}$ \\
\hline 1 & 5 & 7,10 & 0 & 0 \\
\hline 2 & 10 & 7,10 & 0 & 10 \\
\hline 3 & 20 & 7,10 & 0 & 0 \\
\hline 4 & 5 & 14,20 & 0 & 0 \\
\hline 5 & 10 & 14,20 & 0 & 0 \\
\hline 6 & 20 & 14,20 & 0 & 0 \\
\hline 7 & 5 & 16,58 & 0 & 0 \\
\hline 8 & 10 & 16,58 & 0 & 0 \\
\hline 9 & 20 & 16,58 & 0 & 0 \\
\hline
\end{tabular}

In the microbial quantitative test using TPC method, the results on all samples of seawater that have been treated using prototype is obtained. the result is shown that the object does not contain microbes except in crumb rubber filtration sample with $10 \mathrm{lpm}$ discharge and 7.10 $\mathrm{mW} / \mathrm{cm}^{2}$ which still contains $10 \mathrm{cfu}$. With this result, the inactivation of microorganisms in seawater using ballast water treatmet prototipe have the around 99\% efficiency. The result of microbial observation on seawater with quantitative test has been in accordance with the testing protocol, but from the results, it is expected to have an error in the calculation of the number of microbes. The error of this calculation because of the using of aqueous solutions as a mixture in the medium. Aqueous solutions have lower salinity than sea salinity and thought to be less suitable if used as a microbial growth medium diluent. This condition is suspected to cause growth of the microbesin the medium, thus inhibiting or killing the bacteria

To examine the effect of salinity on bacterial growth, further testing is done using turbidity method. In this test, the bacteria in the sample was obtained based on the observation of the turbidity level whose value was raised from the spectrophotometer with Optical Density (OD) unit. In this turbidity test, it is used two blank which consist of sterile aquades and sterile seawater.

The result of turbidity test on water samples shows that OD value is 0.066 , whereas by using sea water blank shows OD value is 0.070 . The results shows that there is difference in OD values both in the sample with aquades 
and sterile seawater. The differences in the values that obtained may be due to the influence of salinity levels. Salinity that is inconsistent with the existing microbial conditions in the aquades blank, allows the microbe to experience lysis during the dilution process. Which is the reason when the object is tested with a spetrophotometer will produce a lower value than the sample. This value proves that differences in environmental conditions of microbial such as salinity will affect microbial growth. These resulted in error / invalid value of microbial calculations using aquades diluents. However, the difference in value from OD test is very small, which is 0.004. This indicates that the effect of salinity is not so significant.

In addition to the test of the turbidity of sea water samples, the turbidity test on sea water samples that have been processed in a ballast water treatment prototipe is conducted. From this test, obtained the value of OD as in Table 3 below.
From Table 3, it is shown that with filtration and UV irradiation treatment resulted in a decrease in OD value of 0.048. From this result it can be analyzed that the salinity difference in the growth medium does affect microbial growth, but based on the turbidity test the value is relatively small. While the dominant factor onthe inactivation of microbial seawater pathogens in this research is because of inactivation produced by prototype of ballast water treatment.

\subsection{Quantitative Analysis of Microbial Water Using} TPC Method With Sterile Sea Solvent

In the analysis of microbial content of sea water, it is used sterile sea water as a medium Na solvent. Sea water is used as a $\mathrm{Na}$ solvent to meet the salinity level that is enhanced by marine bacteria in order to grow normally in bacterial growth medium. From this observation obtained results as in Table 4

In the observation of seawater sample susing TPC method with medium and sterile sea water obtained inconsistent various results. This is similar to the result in experiment using carbon filtration as in shown onTable 5.

TABLE 3.

TABLE OFTURBIDITY TESTING WITH AQUADES STERIL BLANK

\begin{tabular}{lc}
\hline \multicolumn{1}{c}{ Sample } & OD value \\
\hline Exsisting & 0,066 \\
\hline $\begin{array}{l}\text { 16,58mW/cm2 } \\
\text { UV-C }\end{array}$ & 0,018 \\
\hline Carbon & \\
filtration+ & \\
16,58mW/cm2 & 0,018 \\
UV-C & \\
\hline
\end{tabular}


TABLE 4.

TABLE OF MICROBIAL QUANTITATIVE ANALYSIS USING TPC AND STERILE SEA SOLVENT

\begin{tabular}{ccccc}
\hline $\begin{array}{c}\text { Eksperiment } \\
\text { number }\end{array}$ & Debit (lpm) & $\begin{array}{c}\text { UV dose } \\
(\mathrm{mW} / \mathrm{cm} 2)\end{array}$ & $\begin{array}{c}\text { Number of alive } \\
\text { microbesA(Cfu/ml) }\end{array}$ & $\begin{array}{c}\text { Number of alive } \\
\text { microbesB(Cfu/ml })\end{array}$ \\
\hline 1 & 5 & 7,10 & $9,6 \times 10^{4}$ & $4,0 \times 10^{4}$ \\
\hline 2 & 10 & 7,10 & $1,5 \times 10^{5}$ & $1,3 \times 10^{3}$ \\
\hline 3 & 20 & 7,10 & $8,3 \times 10^{6}$ & $1,1 \times 10^{3}$ \\
\hline 4 & 5 & 14,20 & 0 & $6,0 \times 10^{9}$ \\
\hline 5 & 10 & 14,20 & 0 & $1,0 \times 10^{7}$ \\
\hline 6 & 20 & 14,20 & 0 & $2,0 \times 10^{9}$ \\
\hline 7 & 5 & 16,58 & $7,2 \times 10^{4}$ & $3,1 \times 10^{2}$ \\
\hline 8 & 10 & 16,58 & $2,6 \times 10^{2}$ & $1,0 \times 10^{5}$ \\
\hline 9 & 20 & 16,58 & $7,5 \times 10^{6}$ & \\
\hline & $*$ A : Carbon filtration & & \\
& $*$ B : Crumb rubber filtration
\end{tabular}

TABLE 5.

TABLE OF MICROBIAL QUANTITATIVE ANALYSIS USING TPC AND STERILE SEA SOLVENT

\begin{tabular}{cccc}
\multicolumn{4}{c}{ STERILE SEA SOLVENT } \\
\hline $\begin{array}{c}\text { Eksperiment } \\
\text { number }\end{array}$ & Debit (lpm) & $\begin{array}{c}\text { UV dose } \\
(\mathrm{mW} / \mathrm{cm} 2)\end{array}$ & $\begin{array}{c}\text { Number of alive } \\
\text { microbesA(Cfu/ml) }\end{array}$ \\
\hline 3 & 20 & 7,10 & $8,3 \times 10^{6}$ \\
\hline 6 & 20 & 14,20 & 0 \\
\hline 9 & 20 & 16,58 & $7,5 \times 10^{6}$ \\
\hline
\end{tabular}

$* \mathrm{~B}:$ Crumb rubber filtration

TABLE 6.

TABLE OF TURBIDITY TESTING WITH SEA WATER STERIL BLANK

\begin{tabular}{lc}
\hline \multicolumn{1}{c}{ Sample } & OD value \\
\hline Exsisting & 0,070 \\
\hline $16,58 \mathrm{~mW} / \mathrm{cm} 2$ & 0,070 \\
UV-C & \\
\hline Carbon & \\
filtration+ & 0,010 \\
$16,58 \mathrm{~mW} / \mathrm{cm} 2$ & \\
UV-C & \\
\hline
\end{tabular}

Table 5 shown that in the experiment of seawater treatment at $20 \mathrm{lpm}$ discharge with increasing UV irradiation dose did not result increasing number of microbial inactivation. In sample number one with UV dose $7.10 \mathrm{~mW} / \mathrm{cm}^{2}$ the number of living microbes around $8.3 \times 106 \mathrm{Cfu}$. This amount is larger than the amount of microbial water samples in the existing condition that is around $1.31 \mathrm{x} 105 \mathrm{cfu}$. In the second sample with UV dose of $14.21 \mathrm{~mW} / \mathrm{cm}^{2}$ showed good inactivation, in this sample there was no surviving microbes, but the condition of sample number two was not supported by the consistency of inactivation in sample number three. In the third sample with UV doses greater than the second sample of $70 \mathrm{~mW} / \mathrm{cm}^{2}$, it showed that living microbes rose to $7.5 \times 106 \mathrm{Cfu}$. This amount also exceeds the number of microbes in the existing condition.

The inconsistency of seawater sample test results in this study is hypothesized to be caused by several causes. The first hypothesis of inconsistencies caused by prototype performance factors that can not work optimally in providing treatment to seawater so there are still a lot of living microbes. The second hypothesis inconsistency is caused by the contamination of the microbial sea water derived from the medium diluent so that it has not died even though it has been sterilized before. The third hypothesis of inconsistency is caused by microbes that grow significantly when implanted in the medium. The microbes grow significantly because they get an ideal environment that has salinity, ph, water content and other supporting factors that support microbial growth.

To prove the truth of the three hypotheses, a more indepth quantitative analysis is conducted using turbiditi method. The results of this turbidity test is shown in Table 6.

Table 6 shows that the presence of UV irradiation treatment does not decrease the OD value, whereas with UV filtration and irradiation treatment the value is decreased by 0.060 . From this result it can be concluded that the first hypothesis is considered less precise because the prototype can inactivate microbes well when when combining UV irradiation with filtration. In the second hypothesis, where inconsistency of inactivation is caused by microbial contamination of seawater on the medium to be assessed has very little potential. This is because the microbial endospores take more than TPC incubation time used is 12 hours. The third hypothesis is considered to be the most likely hypothesis to occur than any other 
hypothesis. According to Aguskrisno (2011), factors such as medium, wetness, $\mathrm{pH}$, temperature is still good. We can calculate how large the amount of $1 \mathrm{E}$. coli after it is allowed to breed 24 hours, that is $272=22$ $\mathrm{x} 270$ or more than $4 \times 1021$. From that case it is probable that the medium that has been mixed with sterile sea water into an environment that is for the Microbes to reproduce, so that in the incubation period for 12 hours microbes grow significantly.

\section{CONCLUSIONS}

Based on the results of sea water treatment experiments using ballast water treatment prototype, it can be concluded that

1. Prototype of ballast water treatment can inactivate microbial samples of marine waters by $99 \%$ when prototype is run using carbon filtration or crumb rubber, with $20 \mathrm{lpm}$ in water capacity and $7.10 \mathrm{~mW}$ $/ \mathrm{cm}^{2}$ in UV irradiation dose.

2. Carbon filter has better performance than crumb rubber filter in filtering sea water. This is shown in the sample of seawater treated at a discharge of 10 $1 \mathrm{pm}$ with UV dose of $7.10 \mathrm{~mW} / \mathrm{cm}^{2}$, on the carbon filtration, the number of bacteria growing around 0 $\mathrm{Cfu}$, while in the bacterial crumb rubber filtration grows around $10 \mathrm{Cfu}$.

3. Ballast water treatment using filtration method is not able to reduce the value of water turbidity that conduct by microbes in OD level 0.070 . While with aexperiment with Escherichia coli. the treatment of filtration and UV radiation the OD level will decrease to 0,010 .

\section{ACKNOWLEDGEMENT}

The authors are grateful to the Institut Teknologi Sepuluh Nopember (ITS) for grant research.Therefore, The preliminary study of the development of ballast water treatment prototipe can be completed.

\section{REFERENCES}

[1] International Maritime Organisation, "Ballast Water Management Convention," in International Covention for the Control and Management of Ships, 2004.

[2] European Maritime Safety Agency. (2013) EMSA. [Online]. http://www.emsa.europa.eu

[3] Harley dan Prescott, Laboratory Exercises in Microbiology 5th Edition. New York: McGraw-Hill Companies, 2002.

[4] Z.J., Zhang, L., Shi, Y., Shao, J. C., Leng, X. D. \& Zhao, Y Ren, "Microorganism Removal from Ballast Water using UV Irradiation," Journal of Residuals Science \& Technology, pp. 13(1), 31-35, 2016.

[5] Z., Butkus, M.A., Xie, Y.F., Tang, "Crumb rubber filtration: a potential technology for ballast water treatment," Chemosphere, pp. 410-423, 2006. 